\title{
CURRICULUM REVISION AND CULTURAL CHANGE
}

\author{
A JOINT FACULTY DEVELOPMENT AND FACULTY \\ GOVERNANCE APPROACH
}

Terre H. Allen, David A. Horne, Ingrid M. Martin, Michael E. Solt, California State University, Long Beach

Typically faculty development is not closely aligned with faculty governance. However, faculty development and faculty governance can find opportunities to work together to achieve transparent, rapid, and systematic curriculum revision and cultural change. Specifically, we describe the process of revision of a master's of business administration (M.B.A.) curriculum in which faculty development and faculty governance worked together to provide continuous assistance, opportunities for frequent discussion, periodic review, and faculty programming to achieve curriculum and course redesign for integrative learning and integrative teaching practice.

Curriculum revision is one of the most contentious issues in academia (Johnson, 2001). Many faculty come only reluctantly to the table to negotiate curriculum revision with attitudes that can be characterized as, "If you change it, don't change my course," and, "This is my course and I've been teaching it this way, and it's been working." Nevertheless, global, societal, and legislative mandates require that universities prepare students for twenty-first-century work. Business executives and business educators agree that M.B.A. learners require an integrative curriculum because business problems are not limited to a single academic domain (Latham, Latham, \& Whyte, 2004; Rapert \& Curington, 2010). However, little is known about best practices in curriculum change for such cross-functional academic programs.

Johnson (2001) studied how 147 school districts engaged in curriculum revision and provided a set of best practices for accomplishing 
revision and change. The project explored in this chapter applied Johnson's best practices to establish a multilevel yet rapid process for curriculum revision in a large, multidepartment college of business.

\section{Establishing the Need for Curriculum Revision}

The curriculum revision process began in a typical fashion, with preparation for an accreditation visit to the College of Business Administration (CBA) at California State University, Long Beach. The Association to Advance Collegiate Schools of Business required the college to establish a student learning task force to evaluate the strengths and weaknesses of the undergraduate and graduate curricula. Results indicated low alumni satisfaction with their learning in the M.B.A. program and prompted an urgent focus on the M.B.A. curriculum. A task force was established to examine the attributes of the M.B.A. curriculum and review how other M.B.A. programs were addressing graduate business education. The task force recommended a complete revision of the M.B.A. curriculum to meet the needs of students and the demands of the local and global business community.

The M.B.A. task force:

- Undertook review of the core curriculum of five top M.B.A. programs, five comparable M.B.A. programs, and ten M.B.A. programs in the region with which we directly compete

- Conducted alumni surveys and focus groups

- Held interviews and focus groups with current M.B.A. students

- Participated in Association to Advance Collegiate Schools of Business conferences on curriculum innovation

- Held discussions with administrators from other programs that had undergone curriculum revision

- Engaged in open discussions and brainstorming sessions with small groups of faculty across the college

- Conducted discussions with university administrators

- Consulted with external curriculum experts

Results indicated that one of the most profound weaknesses in the M.B.A. program was its lack of focus on student ability to think critically. The task force recognized that instead of encouraging students to think critically across disciplinary boundaries, our faculty were forcing memorization of compartmentalized information. Lorange (2010) 
suggests that "academics must work across boundaries to create learning, teaching, and research environments that embrace a 'we, we, we' spirit ... where business is seen as a whole, not as a series of parts" (p. 38). In a similar vein, Bisoux (2009) notes that the challenge is to create programs that are flexible, integrated, and experiential. The dean, the M.B.A. director, and the M.B.A. curriculum committee envisioned a curriculum that integrated the functional areas of the M.B.A. program.

The M.B.A. task force identified integrative learning as the ideal approach to achieve the vision (Bisoux, 2009; Lorange, 2010). The common denominator of integrative learning programs is a problembased approach that simulates the business world, allowing students to hone their critical thinking skills in a business decision-making environment that crosses functional areas. Such a dramatic curricular redesign meant that there had to be a corresponding change in pedagogical tools and strategies to teach the new courses, necessitating that faculty learn to teach outside their comfort zones. In addition, the proposed change would require that faculty coordinate regularly across departments to exchange ideas and information and work together both in and out of the classroom. Faculty would need to look beyond courses and their own functional silos to focus on business problems and processes.

The M.B.A. task force next conducted a SWOT analysis, looking at strengths (S) and weaknesses (W) of each program and the opportunities $(\mathrm{O})$ and threats $(\mathrm{T})$ in the market for each program. The result was a succinct set of points that was mapped onto a two-by-two SWOT matrix. This team passed its work to the graduate curriculum committee to establish program-level learning outcomes:

Critical thinking skills. Students will demonstrate conceptual learning, critical thinking, and problem-solving skills.

Interpersonal, leadership, and team skills. Students will demonstrate interpersonal communication and leadership skills to work in a dynamic and diverse world independently and in a team environment.

Social responsibility skills. Students will demonstrate awareness and knowledge of social responsibility, ethical leadership, and corporate citizenship in the domestic and global environment.

Business functions. Students will demonstrate knowledge of today's dynamic business environment (business functions, practices, and related theories) and be able to integrate this functional knowledge in order to address business problems. 
Domestic and global environment. Students will demonstrate knowledge of today's dynamic business environment (legal, regulatory, political, cultural, and economic), especially the links between our region and the global business world.

Quantitative and technical skills. Students will demonstrate the quantitative and technical skills needed to analyze, interpret, and communicate business data effectively and to improve business performance.

Initially many faculty voiced opposition to the proposed substantive changes in the curriculum. The dean recognized the need to change the culture of teaching and learning in the college and recommended that the graduate curriculum committee chair and the M.B.A. program director meet with the university faculty development director for suggestions and recommendations on how to bring resistant faculty to the table to discuss their issues, and navigate curriculum, teaching, and learning changes simultaneously. As Latta (2009) suggested, the prospect of working toward M.B.A. curriculum revision and cultural change in teaching and learning presented an important opportunity for faculty development to support broad strategic goals of the college.

University trustees had earlier established a professional fee assessed to students of the M.B.A. programs that would be used to maintain accreditation, expand career services for M.B.A. students, and recruit a more diverse M.B.A. student body. The fee provided funds for the faculty development required to be successful in a curriculum revitalization process. The provost and dean argued that the use of the fee constituted an investment in the future of our program.

The dean established a cultural change team based on Kotter's (2001) assertion that the linchpin between ideas and action is aligning people who understand the vision and are committed to its achievement. The cultural change team was made up of the dean, the M.B.A. program director, the chair of the M.B.A. curriculum committee, and the university faculty development director. The team included the university faculty development director because the dean wanted to ensure that sufficient professional development opportunities would be designed specifically to meet the needs for curriculum and cultural change to a learner-centered and integrative M.B.A. program of study.

\section{Navigating Curriculum and Cultural Change}

Johnson's (2001) best practices were selected as the guiding principles for navigating curriculum and cultural change among the CBA faculty. The team adopted four guiding principles for our work: 
1. Administrators, faculty, students, alumni, and community partners must be involved in the curriculum revision process.

2. The time frame for revision and training should be short in duration; our goal was to launch a pilot cohort group at the end of the second year of internal study.

3. Participants should have access to continuous assistance, opportunity for frequent discussion, and periodic review throughout the entire process.

4. Curricular revitalization would necessitate changes in classroom instructional practices. In addition, the team recognized that a multitude of administrative issues required attention and that the process required simultaneous actions on multiple fronts.

We implemented these principles in the three phases of our project.

\section{Phase 1: Setting the Stage for Change}

Johnson's (2001) guiding principles provided the framework for a series of events aimed at simultaneous curriculum and cultural change. The events were designed to involve faculty, students, alumni, local businesses, and administration actively throughout the change process. The events were distinct, each with a definite purpose and audience. They were spread over an academic year, timed at deliberate intervals; held away from the college in university facilities designed to accommodate conferences; and provided breakfast and lunch. All events were planned, coordinated, and facilitated by the cultural change team and the faculty development director.

The first event, the M.B.A. retreat, was organized around the theme, "Is Change in the M.B.A. Curriculum Necessary?" The retreat provided a context for engaging the faculty and introducing Johnson's (2001) principles. All faculty (tenured, tenure track, and adjunct) were invited to attend; more than sixty of the seventy-five participated. The first half of the session was a moderated open discussion about the existing program and the results of the M.B.A. task force analysis. A general consensus emerged that the curriculum was out of step with the business world, and change was necessary. Next, faculty were divided into discussion groups to explore possible alternatives of how to achieve curriculum change. Each table presented its ideas to the group, and a question-and-answer period followed. Recognizing the importance of socializing as a means to build relationships and foster a culture of inclusion and collaboration, we built into the event a social hour after the meeting. 
The M.B.A. curriculum committee used oral and written feedback from this event to continue drafting the revitalized M.B.A. curriculum. The second event, the M.B.A. Revitalization Conference, was presented in an academic conference format. Johnson's (2001) principle of engaging administration, faculty, students, alumni, and community provided the foundation for planning this event. More than one hundred faculty, alumni, current students, advisory board members, high-level university administrators, and community leaders participated. Four panel presentations, each with a moderator and faculty presenters, explored specific possible format changes of the revitalized program: orientation, disciplinebased core, integrative core, and integrative electives. Faculty panelists also demonstrated that proposed changes had academic integrity and that faculty from different departments could work together on curriculum revision. Faculty panel participants received a stipend for attending two half-day faculty development workshops to coordinate the panel presentations. A question-and-answer session at the event's conclusion resulted in a spirited discussion of what should be included in a twenty-first-century M.B.A. curriculum. Faculty, alumni, current students, and community business leaders engaged in public dialogue about the proposed changes and program learning outcomes.

The first two events resulted in sufficient feedback and idea generation that the graduate curriculum committee and M.B.A. director formulated a revised curriculum plan (Table 11.1). Johnson's (2001) second and third principles recommend a short time frame and access to continuous assistance; therefore, within two months, the cultural change team quickly followed up the revitalization retreat with a third half-day workshop. Prior to the workshop, faculty were asked to suggest topics that would serve as potential themes for integrative M.B.A. courses-for example, sustainability, global enterprise, and innovation. The graduate curriculum committee identified two types of courses from those suggested by faculty: narrow integrative courses, comprising two departments or areas of study; and broad integrative courses, spanning three or more departments or areas of study.

The Revitalized M.B.A. Workshop, attended by more than sixty faculty, served as a hands-on demonstration of turning cross-disciplinary ideas into potential integrative courses. It began with an empowering message from the dean, an overview of the purpose and plan for the workshop activities, and brief presentations on integrative course design and assessment. Participants were assigned to specific theme tables based on their specified interests to draft ideas as to how each theme could evolve into an integrative course. Faculty teams presented their ideas to 
Table I I.I Original and Revitalized M.B.A. Curricula

\begin{tabular}{|c|c|c|c|c|}
\hline \multicolumn{2}{|c|}{$\begin{array}{l}\text { Original M.B.A. Curriculum (based on } \\
\text { three-unit courses) }\end{array}$} & $\begin{array}{l}\text { Total } \\
\text { Units }\end{array}$ & $\begin{array}{l}\text { Revitalized M.B.A. } \\
\text { Curriculum } \\
\text { (based on four-unit } \\
\text { courses) }\end{array}$ & $\begin{array}{l}\text { Total } \\
\text { Units }\end{array}$ \\
\hline \multicolumn{2}{|l|}{$\begin{array}{l}\text { A. First year } \\
\text { Orientation } \\
\text { (Optional) }\end{array}$} & 0 & $\begin{array}{l}\text { Orientation } \\
\text { (required) }\end{array}$ & 2 \\
\hline $\begin{array}{l}\text { Core courses- } \\
\text { for nonbusiness } \\
\text { undergraduates or } \\
\text { if taken more than } \\
\text { three years earlier }\end{array}$ & $\begin{array}{l}\text { Basic courses } \\
\text { in accounting, } \\
\text { finance, } \\
\text { management, and } \\
\text { marketing }\end{array}$ & 0 to 12 & $\begin{array}{l}\text { Online diagnostic } \\
\text { tests and tutorial } \\
\text { program for } \\
\text { prerequisite skills }\end{array}$ & 0 \\
\hline $\begin{array}{l}\text { Core courses } \\
\text { required for all } \\
\text { M.B.A.s }\end{array}$ & $\begin{array}{l}\text { Courses in } \\
\text { accounting (one), } \\
\text { finance (one), } \\
\text { human resource } \\
\text { management } \\
\text { (one), information } \\
\text { systems (two), } \\
\text { marketing (one) }\end{array}$ & 21 & $\begin{array}{l}\text { One course each } \\
\text { in accounting, } \\
\text { finance, } \\
\text { information } \\
\text { systems, } \\
\text { management, and } \\
\text { marketing }\end{array}$ & 20 \\
\hline $\begin{array}{l}\text { B. Second year } \\
\text { Elective courses }\end{array}$ & $\begin{array}{l}\text { Four required } \\
\text { from twenty- } \\
\text { four available: } \\
\text { accounting (two); } \\
\text { finance (four), } \\
\text { human resource } \\
\text { management } \\
\text { (three), information } \\
\text { systems (two), } \\
\text { management (four), } \\
\text { marketing (six) }\end{array}$ & 12 & $\begin{array}{l}\text { Integrative core: } \\
\text { two eight-unit } \\
\text { sequences required: } \\
\text { Sustainable } \\
\text { Business } \\
\text { Organizations } \\
\text { and Customer } \\
\text { Relationship } \\
\text { Management; } \\
\text { and an integrative } \\
\text { elective course (one } \\
\text { required from six } \\
\text { available) }\end{array}$ & $\begin{array}{r}16 \\
4\end{array}$ \\
\hline International & $\mathrm{NA}$ & NA & $\begin{array}{l}\text { International } \\
\text { experience/study } \\
\text { abroad }\end{array}$ & 3 \\
\hline Capstone & Capstone course & 3 & $\begin{array}{l}\text { Practicum- } \\
\text { community-based } \\
\text { project }\end{array}$ & 3 \\
\hline Total & & $36-48$ & & 48 \\
\hline
\end{tabular}


the entire group; prizes and friendly competition contributed to the fun and excitement. The workshop resulted in a noticeable cultural shift from, "Why should we do this?" to, "How can we do this?" Certainly not every faculty member embraced these initiatives, and some faculty voiced concerns about how to design integrative learning experiences that would produce the desired learning outcomes. This event operationalized Johnson's (2001) third principle, access to continuous assistance, by providing faculty with an opportunity to review the feedback and work accomplished thus far and work together on idea generation for curriculumcentered activities.

The cultural change team met to review progress and faculty feedback from the workshop. In accordance with Johnson's (2001) third principle, the team determined that a systematic faculty development program for designing integrative courses was necessary to move revitalization forward. The faculty development director drafted, and the dean and the M.B.A. curriculum committee approved, a proposal for a blended learning (face-to-face and online) course called Designs4Integration. The dean and the graduate curriculum committee decided that faculty who would teach in the revised curriculum would be required to participate in the course and would be awarded a three thousand dollar stipend for course completion. Requirements for completion were that each team submit a standard course outline, syllabus, assignments, and recommended assessments ready for curriculum approval at the department, college, and university levels. Reflecting our commitment to Johnson's (2001) first principle, a community partner who was also an alumnus was asked to review the Designs4Integration proposal. He gave his enthusiastic endorsement and provided some recommended resources.

\section{Phase 2: Providing Faculty Development}

The deliverables for curriculum approval required that faculty from different functional areas (accounting, finance, information systems, marketing, and management) collaborate to design integrative courses. Collaborative course design, collaborative teaching, and integrative learning were all new concepts to the vast majority of faculty in the college. Naturally most faculty were uneasy about putting the ideas of integrative learning into practice. As such, the university faculty development director worked toward designing a learning experience that would produce the intended outcomes and deliverables and educate faculty about integrative learning, collaborative course design, and collaborative teaching practices. 
Designs4Integration is conducted over three weeks, with three face-toface half-day sessions. It is housed on our learning management system. All faculty were enrolled as students; in summer 2010, thirty-four participated, and in winter 2011, fifteen did so. The course has seven developmentally sequenced modules:

Module 1: Introduces faculty to the course and intended outcomes and deliverables.

Module 2: Provides a variety of readings exploring integrative learning and integrative learning practices.

Module 3: Addresses issues in collaborative teaching for integrative learning and includes readings on cultivating colleagueship, collaborative course design, and collaborative teaching strategies.

Module 4: Addresses culturally responsive pedagogy by situating case method practices (www.hbs.edu/teaching/case-method-inpractice/) as a culturally responsive way to achieve integration of course content in the classroom.

Module 5: Addresses technology in integrative learning.

Module 6: Designing Your Course, adapted from Fink (2003), which leads faculty teams through a variety of activities that result in specific deliverables. Each course team, working within a theme area, was led through a collaborative process of building strong primary components (determining learning goals, building learning activities, building assessment and feedback), assembling those components into a coherent whole (designing the course structure, the standard course outline and syllabus), and finalizing the learning material for review (university policies and practices).

Module 7: Asked teams to reflect on their process and consider feedback and leadership issues.

Face-to-face sessions were half-day workshops that provided time for discussion of module specifics, questions, and teamwork. Blended instruction allows team members to work in collaborative online groups and to house all documents and resources (curriculum information, assessment information, accessibility requirements, academic journal websites, campus policy statements) at one point of access. In addition, groups posted deliverables on the course site for all participants to review. The summer 2010 offering of Designs4Integration resulted in seven integrative course proposals: Sustainability and the Business Enterprise, Customer Relationship Management, e-Commerce, Global Investments, 
Innovation and the Business Enterprise, Financial Statement Analysis, and Mergers and Acquisitions.

Feedback from the summer 2010 offering indicated that faculty were most apprehensive about sharing their teaching time with other faculty. In addition, faculty remained unsure about how to ensure that students integrate information from the areas of study presented in the class. Reflecting Johnson's (2001) fourth principle, changes in instructional processes, the faculty development director developed a second course, Teaching4Integration, to help faculty create learner-centered and integrative classroom experiences. Again, we asked our alumni community partner to review the Teaching4Integration proposal, and he gave it enthusiastic support.

Teaching4Integration leads faculty through a three-part model (content delivery, active learning for integration, and reflection, synthesis, and application) of class organization and delivery. Each part is accompanied by recommended student work, activities, and assessment. Faculty spend the least amount of time delivering content individually. Active learning for integration is facilitated and coordinated by both or all faculty together, as is the reflection, synthesis, and application portion of the class. Harvard Business School case studies provide the basis for content integration. During the Teaching4Integration workshop, teaching teams work toward establishing comfort and competence in collaborative teaching, a paradigm shift in pedagogy for most faculty.

\section{Phase 3: Bringing It All Together}

Bringing the process to fruition in the form of a completed curriculum required some planning at a strategic level and included a curriculum matrix, assessment, and sustaining support.

\section{DEVELOPING THE CURRICULUM MATRIX}

Deans may lead and manage, but the college constitution specifies that approval of a new curriculum requires a vote of tenured and tenure-track faculty. An important step toward gaining faculty acceptance was the development of a curriculum matrix. Faculty were asked to address a map of course topics that contributed to the newly defined M.B.A. program outcomes. Numerous content redundancies were revealed during this process. Faculty began to buy into the idea that curriculum revision might reduce redundancies across courses and functional areas and might be acceptable since topics and concepts were reorganized into new courses and not dropped from the new curriculum. 
Curriculum matrices from each department were combined to develop the overall M.B.A. curriculum map that delineated the full set of concepts, topics, and theories by functional area. Faculty had to come together to discuss how and where concepts could be integrated within the new curriculum. By charting what should be taught, when it should be taught, and how it should be configured, faculty produced a plan for achieving learning that could be used with assessment data to inform further modifications in the curriculum.

\section{ASSESSING PROGRAM-LEVEL OUTCOMES}

Another important step toward the acceptance of M.B.A. revitalization was the explicit recognition that assessment had to be built into the new program in a manner that would link learning objectives, accreditation requirements, and the shortcomings uncovered in our SWOT analysis: The college associate dean for accreditation guided the development of the assessment process. She identified an outside expert who worked with the curriculum committee to design and implement a portfolio assessment plan that was integrated into the new curriculum. The works collected include students' expectations about their M.B.A. education as related to the learning goals, their participation in various projects and efforts, their self-reflections, samples of their work related to outcomes being assessed, and documents that demonstrate their growing mastery of the M.B.A. curriculum. The portfolio is not merely a tool to assess the learning impact of the revitalized curriculum but also a marketing tool for M.B.A. students as they search for employment after graduation.

\section{SUSTAINING SUPPORT}

We reached out to other business schools that had undertaken this type of major educational paradigm shift. The most important piece of advice that we received was to engage as many participants as possible in the change process with the understanding that there would always be a few who would never join the shift to a new way of teaching and learning. The stakeholder engagement process needed to be constant, and it needed to address the points of resistance, concern, and risks that faculty and others identified.

Early in the curriculum revision process, college administrators recognized that the proposal for M.B.A. revitalization required significant support from other units on campus. Specifically, the university process for proposing any new course, let alone an entirely new curriculum, was a 
well-defined procedure with established time lines, policies, and deadlines. The aggressive timetable established early in the process had the goal of offering the new curriculum in the next academic year. This timetable meant that classes that were only being dreamed of had already passed the usual approval deadlines. Other obstacles emerged during cross-campus discussions, and each presented unique challenges to keep the effort on track. Each time an obstacle emerged, the cultural change team met to strategize a solution, and one or more team members followed through on making the solution a reality.

Obtaining acceptance across the campus required constant communication with university leaders. Most administrative service units appreciated consultation about implementation issues that they would need to accomplish. Numerous suggestions about how various components would or would not work within the current university system altered some elements of the overall intended results, but the changes were minor. All in all, working with the administration demonstrated that truly good ideas do not always have to adhere to the rigid rules of the institution, but with the proper level of support across the university, they can be given a chance.

\section{Conclusions and Recommendations}

The three phases outlined in this chapter represent significant milestones of successful and swift curriculum revitalization and cultural change. The process involved faculty development and faculty governance for continuous assistance, opportunities for frequent discussion, periodic review, and faculty development for curriculum design, course redesign, integrative learning, and integrative teaching practice. The phases outlined in this chapter can be replicated or adjusted to meet the needs of any group working toward curriculum revision or paradigm shift.

Johnson's (2001) guiding principles were central to establishing events and activities that fostered the changes we desired. They enabled us to assess our processes and to plan for future events. Specifically, we included administration, faculty, students, alumni, and community partners in our processes whenever possible (principle 1). The process took place from fall 2009 (M.B.A. Revitalization Retreat) through summer 2010 (Designs4Integration). Thus, a new curriculum was conceived and new courses were developed and moved through the curriculum process in one academic year (principle 2). A new cohort of students started the revitalized M.B.A. in fall 2010. 
The two faculty development courses that supported curriculum change reflect principles 3 and 4. Making faculty development an integral part of curriculum change situates faculty development as a provider of continuous assistance. Housing both faculty development courses on the learning management system provides faculty with continuous access to learning material, curriculum material, assessment material, and course material. The semester prior to teaching a new integrative M.B.A. course, faculty use Teaching4Integration, which reflects principle 4 in that it is focused on changes in instructional processes.

The events and activities documented in this process represent strategic efforts to generate excitement, foster meaningful dialogue, demonstrate cooperation, engage participants, and provide social opportunities for relationship building and collaborative partnerships. The planning for each component involved significant efforts from the college leadership, the faculty development expert, faculty governance groups, and staff. The results were impressive. Each event was well attended and had people asking, "What's next?" Each event earned the attention of the university administration, and they are encouraging other university colleges to duplicate this curriculum and cultural change process.

Faculty development professionals need not be involved in large-scale cultural change to use the ideas and resources found in Designs4Integration and Teaching4Integration. However, Latta's (2009) call for faculty developers to support broader university efforts provides a valuable recommendation. Teaming with campus partners to support strategic change efforts adds value and visibility to faculty development activities. Faculty development and faculty governance indeed make good partners for curriculum revision.

\section{REFERENCES}

Bisoux, T. (2009, May/June). Next generation education. BizEd, 8, 24-30. Fink, D. L. (2003). Creating significant learning experiences: $A$ n integrated approach to designing college courses. San Francisco, CA: Jossey-Bass. Johnson, J. A. (2001). Principles of effective change: Curriculum revision that works. Journal of Research in Education Leadership, 1(1), 5-18.

Kotter, J. P. (2001). What leaders really do. Harvard Business Review, 12, 3-12. Latham, G., Latham, S. D., \& Whyte, G. (2004). Fostering integrative thinking: Adapting the executive education model to the M.B.A. program. Journal of Management Education, 28(1), 3-18. doi:10.1177/1052562903252647 
Latta, G. F. (2009). Maturation of organizational development in higher education. In L. B. Nilson \& J. E. Miller (Eds.), To improve the academy: Vol. 18. Resources for faculty, instructional, and organizational development (pp. 32-71). San Francisco, CA: Jossey-Bass.

Lorange, P. (2010, January/February). A new model for management education. $B i z E d, 1,38-41$.

Rapert, M. I., \& Curington, W. P. (2010). Navigating the sea of change: Developing and implementing an interdisciplinary undergraduate core curriculum. Journal of Innovative Educational Strategies, 1(1), 38-46. 